\title{
Main mental disorders in crack-cocaine users treated at Psychosocial Care Centers for Alcohol and Drugs in the city of Recife, Brazil
}

\author{
Principais transtornos mentais em usuários de crack em tratamento nos \\ Centros de Atenção Psicossocial Álcool e Drogas na cidade do Recife, Brasil
}

Antonio Gomes de Castro Neto, ${ }^{1,4}$ Diego César Nunes da Silva, ${ }^{2}$ Magda da Silva Figueiroa ${ }^{3,4}$

\begin{abstract}
Introduction: Brazil's Northeast region has the highest crack-cocaine consumption in the country. Crack-cocaine has more intense effects than cocaine powder and can cause greater chemical dependence. Psychosocial Care Centers for Alcohol and Drugs (CAPSad) are public health services that provide treatment for drug dependence. It is common for drug users, and particularly crack-cocaine users, to develop mental disorders.

Objective: To evaluate the most common mental disorders in crack-cocaine dependents in treatment at CAPSad in the city of Recife, Brazil.

Methods: The research database "Between rocks and shots: user profiles, consumption strategies, and social impact of crack cocaine" (CEP/CCS/UFPE no. 206/11) was consulted to establish the areas of crack cocaine consumption in the city of Recife.

Results: There were 885 patients in treatment for crack-cocaine use, with a mean age of $29.8 \pm 9.4$ years. The mean duration of drug use was $6.1 \pm 4.6$ years. Most of the patients were males $(80.3 \%)$, had left school at some point between the 1st and 9th grades $(45.6 \%)$, were unemployed and/or seeking employment $(52 \%)$ and used drugs daily (56.4\%). Cocaine chemical dependence was more significant when correlated with use of crack-cocaine and other drugs such as medications and hallucinogens $(p=0.01)$.

Conclusions: Data from this study showed strong associations between crack-cocaine uses and development of mental disorders, particularly when abuse of multiple substances occurs. Based on these data, there is a clear need for coordination of related public policies for support and social reintegration to provide these people with comprehensive care.

Keywords: Crack-cocaine, mental disorders, drug combinations.
\end{abstract}

Resumo

Introdução: A região Nordeste do Brasil possui o maior consumo de crack no país. O crack proporciona efeitos mais intensos comparados aos da cocaína em pó, podendo causar dependência química maior. Os Centros de Atenção Psicossocial Álcool e Drogas (CAPSad) são serviços públicos de saúde que promovem o tratamento para dependência de drogas. Normalmente, o uso de drogas pode desenvolver transtornos mentais, principalmente em usuários de crack.

Objetivo: Avaliar os principais transtornos mentais em dependentes de crack em tratamento nos CAPSad da cidade do Recife. Métodos: O banco de dados da pesquisa "Entre pedras e tiros: perfil dos usuários, estratégias de consumo e impacto social do crack" (CEP/CCS/UFPE no 206/11) foi consultado para estabelecer as áreas de consumo de crack na cidade do Recife.

Resultados: Havia 885 pacientes em tratamento devido ao uso de crack, com média de idade de $29,8 \pm 9,4$ anos. A duração média do uso de drogas foi de $6,1 \pm 4,6$ anos. A maioria dos pacientes era do sexo masculino $(80,3 \%)$, com primeiro ao nono ano incompleto $(45,6 \%)$, desempregados e/ou procurando emprego (52\%) e uso diário de drogas $(56,4 \%)$. A dependência química da cocaína foi mais significativa quando correlacionada ao uso associado de crack e outras drogas como medicamentos e alucinógenos ( $p=0,01)$.

Conclusão: Os dados deste estudo mostraram fortes associações entre uso de crack e desenvolvimento de transtornos mentais, particularmente quando ocorre multiuso. Mostra-se a necessidade de coordenação de outras políticas públicas de apoio e reintegração social para atendimento integral a essas pessoas. Descritores: Crack, transtornos mentais, combinações de drogas.

\footnotetext{
1 Programa de Pós-graduação em Ciências Farmacêuticas, Prédio das Pós-Graduações, Centro de Ciências da Saúde, Universidade Federal de Pernambuco (UFPE), Recife, PE, Brazil. 2 Colegiado de Ciências Biológicas, Universidade Federal do Vale do São Francisco (UNIVASF), Campus Ciências Agrárias, Petrolina, $\mathrm{PE}$, Brazil. ${ }^{3}$ Centro de Atenção Psicossocial Álcool e Drogas (CAPSad) Vicente Araújo, Recife, PE, Brazil. ${ }^{4}$ Grupo de Estudos sobre Álcool e outras Drogas, Recife, PE, Brazil.

Financial support: Conselho Nacional de Desenvolvimento Científico e Tecnológico (CNPq).

Submitted Jan 12 2016, accepted for publication May 09 2016. No conflicts of interest declared concerning the publication of this article.

Suggested citation: Castro Neto AG, Silva DC, Figueiroa MS. Main mental disorders in crack-cocaine users treated at Psychosocial Care Centers for Alcohol and Drugs in the city of Recife, Brazil. Trends Psychiatry Psychother. 2016;38(4):227-233. http://dx.doi.org/10.1590/2237-6089-2016-0002
} 


\section{Introduction}

Brazil is the second largest cocaine consumer market in the world, accounting for $20 \%$ of world consumption of the drug. Crack-cocaine is the form of cocaine most consumed in the country. ${ }^{1,2}$ Brazil's Northeast region has the highest crack consumption in the country, accounting for $39 \%(148,000)$ of Brazilian users. ${ }^{2}$ Use of crack-cocaine has become more popular over the past 15 years, primarily because of its lower price and its more intense effects when compared to cocaine powder. ${ }^{3}$

Chemical dependence is a consequence of a pathologic relationship between the individual and the psychoactive substance. Consumption may be initiated for many different reasons, which probably remain after the user has become dependent. However, diagnosing its psychological and physical symptoms individually could be counterproductive and actually encourage consumption, because patients may reason that their consumption is justified because they have been diagnosed with some type of disorder. If diagnoses of chemical dependence are not adequately explained they themselves may become one of the primary harmful effects of use because this erroneous type of interpretation can ultimately be seen as a justification for substance abuse. ${ }^{4}$ Crack-cocaine dependence causes serious public health problems, compounded by significant economic and social problems, and increases rates of morbidity and mortality. ${ }^{5}$ It is common for psychiatric disorders to coexist with abuse and dependence of psychoactive substance and this comorbidity indicative of unfavorable prognosis for treatment of dependence. ${ }^{6}$ Additional disorders can modify symptomology and compromise prognosis, diagnosis, treatment, or all three. ${ }^{7}$ Psychiatric clinics recognize co-occurrence of disorders due to substances use with mental disorders. Psychoactive substance abuse is the most frequent disorder among patients with mental disorders and correct diagnosis of the pathologies involved is of fundamental importance. ${ }^{8,9}$

The complexity of subjects related to the use of psychoactive substances is reflected in the terminology applied, which appears to change every time professional and government committees meet to discuss the issue. One of the difficulties is how to define disorders caused by substances that change brain function. In Brazil, concepts widely accepted internationally from the International Classification of Diseases and Related Health Problems (ICD-10) are used to classify disorders resulting from substance use. ${ }^{10}$

The issue of drug abuse had predominantly been treated from a biomedical perspective, centered on the disease and its cure. However, social, psychological, economic and political implications are evident and should be considered in the overall understanding of the problem. Society culturally isolates drug users with the result that many of them do not share the expectation and desire for abstinence with health professionals and do not even seek treatment because they do not feel that their differences are accepted. ${ }^{11}$

In Brazil, there is currently a movement to study the profile of the crack user population that accesses health services. Cross-sectional studies focused on this clientele are important since services are observing increased demand for treatment of crack users in at their several different service modalities, including hospitalization for detoxification from the substance. Studies have observed a high prevalence of admissions to psychiatric hospitals because of crack use, with or without other drug use. ${ }^{12-14}$

Care for drug users on the Brazilian Unified Health System (SUS) is provided at Psychosocial Care Centers for Alcohol and Drugs (Centro de Atenção Psicossocial Álcool e Drogas, CAPSad). ${ }^{11}$ The CAPSad ensure the provision of specialized care close to where the users live, but problems have been reported related to access and there is evidence of stigmatization in connection with the CAPSad. ${ }^{15}$ There is a need to expand studies in this area because of the high number of drug users, the great social visibility or the problem and the heavy demand for health services. Action plans in this area are dependent on accumulation of more data on the populations of crack-cocaine users who seek treatment on the public health system. Studies investigating services must be preceded by efforts to trace the profile of the population that seeks these services. Any type of selectivity threatens the principles of universality and equity that govern the SUS. ${ }^{16}$

The reform of Brazilian psychiatry has consolidated the care model over the last 30 years. There is no denying the advances that have been made over this period. Perceptible results include the reduction in the number of long-stay beds, greater openness, the diversification and internalization of services such as the CAPSad, construction of a network of services and care strategies such as Therapeutic Residential Services, introduction of comprehensive care beds in general hospitals, street clinics, integration into the Family Health Strategy (ESF) network, and construction of policies for income-generating among others. The traditional, repressive, model of internment that is also still present in the country is inefficient because of the fragility of links between health professionals, the lack of stability of teams, low funding, and insufficiency of services such as beds in general hospitals, CAPSad, clinics, the ESF, damage limitation efforts, street clinics, and halfway houses among others, compounded by little popular participation with the means of control and social 
mobilization that is primarily caused by the prohibitionist drugs policy. The failure of simplistic and reductionist interventions recognizes its target population through the wide range of health and social problems related to drug use, especially crack. The principal care strategy is characterization of users, establishment of the basic principles for intervention and integration into the healthcare network at all levels.

This objective of the study is to identify the principal mental disorders among crack-cocaine users who seek treatment at the CAPSad in the city of Recife.

\section{Methods}

The research database "Between rocks and shots: user profiles, consumption strategies, and social impact of crack cocaine," approved by the research ethics body (record CEP/CCS/UFPE no. 206/11), was consulted to establish areas of crack cocaine consumption in the city of Recife. ${ }^{17}$ This research database includes a survey of medical records for drug users who were receiving care at the CAPSad between July 2010 and June 2011. These drug user treatment and rehabilitation centers are maintained by the government and access is free to the public. A protocol containing 38 questions was completed using data from medical records on 1,957 patients that sought treatment during the study period. All patients provided written consent. Because of the period covered by the database used, the findings best represent the situation at that time.

Only records related to crack-cocaine dependent patients were selected. The parameters used for analysis were: age, gender, educational level, employment status, duration and frequency of drug use, mental disorders diagnosed according to the ICD10 , and main drugs used in combination. The research database used contains additional data on patients in treatment, but because of the nature of the study only the variables mentioned were used.

Correlations between independent variables were evaluated using tests of significance and $95 \%$ confidence intervals and correlations were considered significant when $\mathrm{p}<0.05$. Cluster analysis was conducted to establish correlations between main drugs used in combination with crack-cocaine, when multiple drug use took place, and correlations between mental disorders diagnosed and when there was more than one disorder per patient. Some data were missing from the database. When these situations occurred, the database was marked as unknown. These cases were mainly because patient records had not been filled out completely and there is a possibility it could be detrimental to accurate analysis.

\section{Results}

Of the 1,957 patients that sought treatment, 885 $(45 \%)$ were crack-cocaine users. The mean duration of drug use was $6.1 \pm 4.6$ years with a minimum duration of 1 year and a maximum of 32 years. Table 1 lists the patients'socioeconomic characteristics.

Table 1 - Socioeconomic data on crack-cocaine patients from Psychosocial Care Centers for Alcohol and Drugs (CAPSad), Recife, Brazil

\begin{tabular}{lc}
\hline Variables & Participants \\
\hline Age (SD) & $29.8(9.4)$ \\
Gender & \\
Male (\%) & $711(80.3)$ \\
Female (\%) & $174(19.7)$ \\
Education level & \\
Illiterate (\%) & $25(2.8)$ \\
Only read and/or write (\%) & $20(2.3)$ \\
Graduated 9th grade (\%) & $199(22.7)$ \\
Left school between 1st and 9th grades (\%) & $402(45.6)$ \\
10th-12th grade (\%) & $153(17.3)$ \\
$>12$ th grade (\%) & $16(1.8)$ \\
Unknown (\%) & $67(7.5)$ \\
Employment status & \\
Student (\%) & $34(3.9)$ \\
Formal job (\%) & $95(10.8)$ \\
Informal job (\%) & $129(14.6)$ \\
Unemployed and/or looking for work (\%) & $458(52)$ \\
Retired (\%) & $23(2.6)$ \\
Unknown (\%) & $81(9.2)$ \\
Other (\%) & $61(6.9)$ \\
Frequency of use & \\
Daily (\%) & \\
Weekly (\%) & $129(14.6)$ \\
Occasionally (\%) & $35(3.9)$ \\
Abstinence (\%) & $75(8.5)$ \\
Unknown (\%) & $147(16.6)$ \\
\hline
\end{tabular}

$\mathrm{SD}=$ standard deviation.

The mean age of patients was $29.8 \pm 9.4$ years; $80.3 \%$ were male; $45.6 \%$ had left school at some point between the 1st and 9th grades; and 52\% were unemployed and/or looking for work. There are significant correlation between 1st-9th grade incomplete education level with 27.8 years age ( $p=0.04)$, with being unemployed and/or looking for work employment status $(p=0.01)$, and with male gender $(p=0.001)$. Unemployed and/or looking for work employment status also had a significant correlation with 30.07 years of age $(p=0.03)$. Table 2 shows the principal mental disorders diagnosed in users using ICD-10 criteria. 
Table 2 - Data on mental disorders in crack-cocaine patients at Psychosocial Care Centers for Alcohol and Drugs (CAPSad)

\begin{tabular}{lccc}
\hline Mental disorders & Only one mental disorder & $\begin{array}{c}\text { More than one mental } \\
\text { disorder }\end{array}$ & Total \\
\hline Chemical dependence & 623 & 140 & 763 \\
Mood disorders & 0 & 12 & 12 \\
Schizophrenias & 1 & 23 & 24 \\
Neurotic disorders & 0 & 5 & 5 \\
Personality disorders & 0 & 3 & 3 \\
Others* & 25 & 107 & 132 \\
\hline
\end{tabular}

* Depression; bipolar disorder; persistent mood disorder; psychotic disorders; delusional disorders; unspecified nonorganic psychosis.

Of the 885 crack-cocaine patients, 763 were dependent on cocaine or other drugs. All mental disorders were significantly correlated with each other $(p<0.04)$, with the exception of neurotic disorders with mood disorders $(p=0.1)$. Relationships were established between socioeconomic data and mental disorders. Gender, age, education level, and employment status were significantly correlated with all mental disorders ( $p<0.05)$, except for age with chemical dependence $(p=0.08)$ and neurotic disorders $(p=0.07)$. Gender and personality disorders also exhibited a significant and low correlation ( $p=$ $0.06)$, although the majority of personality disorders were diagnosed in women (66.7\%). Table 3 lists the main drugs used in combination with crack-cocaine.

Table 3 - Socioeconomic data on crack-cocaine patients from Psychosocial Care Centers for Alcohol and Drugs (CAPSad), Recife, Brazil

\begin{tabular}{lc}
\hline Substance & Participants \\
\hline Crack (only) & 64 \\
Crack + alcohol & 45 \\
Crack + tobacco & 24 \\
Crack + marijuana & 65 \\
Crack + cocaine & 6 \\
Crack + inhalants & 2 \\
Crack + alcohol + tobacco & 32 \\
Crack + alcohol + marijuana & 85 \\
Crack + alcohol + inhalants & 5 \\
Crack + tobacco + marijuana & 63 \\
Crack + tobacco + cocaine & 1 \\
Crack + marijuana + cocaine & 10 \\
Crack + alcohol + tobacco + marijuana & 183 \\
Crack + alcohol + marijuana + cocaine + amphetamines & 7 \\
Crack + alcohol + tobacco + marijuana + benzodiazepines & 18 \\
Crack + alcohol + tobacco + marijuana + cocaine + amphetamines + others & 2 \\
Crack + alcohol + tobacco + marijuana + cocaine + benzodiazepines + others & 4 \\
Crack + alcohol + marijuana + cocaine + amphetamines + benzodiazepines + others* & 1 \\
\hline
\end{tabular}

* Medical drugs; hallucinogens.

A total of 64 patients only used crack-cocaine and all the others patients used at least one other drug in combination with crack-cocaine. The largest subset of patients (183) used crack-cocaine, alcohol, tobacco, and marijuana in combination. None of them used the combination crack-cocaine, cocaine, and alcohol. Figure $1 \mathrm{~A}$ illustrates the cluster analysis correlating drugs used in combination with crack-cocaine and Figure
1B illustrates the cluster analysis correlating mental disorders.

Use of alcohol was significantly correlated with amphetamines $(p=0.04)$, benzodiazepines ( $p=$ 0.03 ) and cocaine $(p=0.03)$. Use of tobacco was significantly correlated with amphetamines $(p=0.01)$, benzodiazepines ( $p=0.01)$, and cocaine ( $p=0.04)$. Table 4 shows correlations between mental disorders and use of substance in combination with crack-cocaine. 


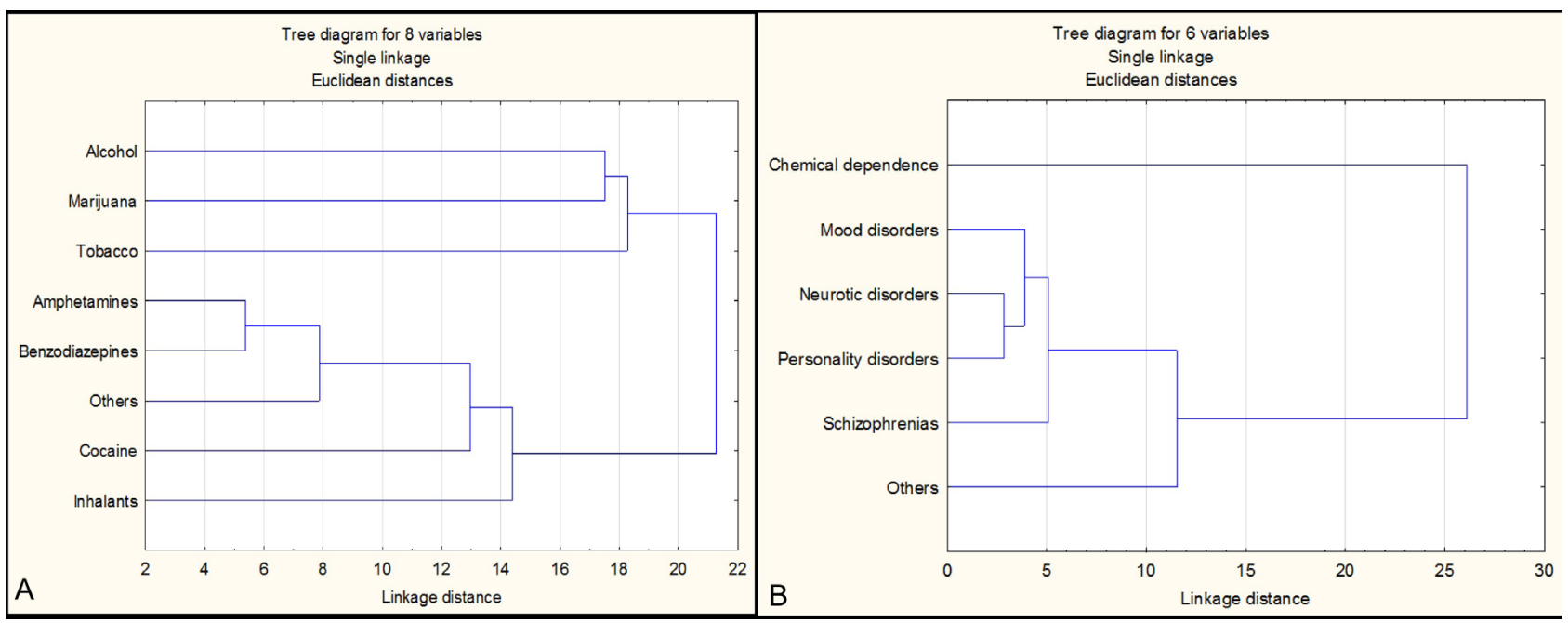

Figure 1 - Cluster analysis correlating drugs used in combination with crack-cocaine (A) and mental disorders (B).

Table 4 - Correlations between mental disorders and multiple substance use

\begin{tabular}{llc}
\hline Mental disorder & Substance & p-value \\
\hline Chemical dependence & Other & 0.01 \\
Mood disorders & Alcohol & 0.01 \\
Schizophrenias & Tobacco & 0.01 \\
Neurotic disorders & Amphetamines & 0.007 \\
Personality disorders & Amphetamines & 0.005 \\
Others & Inhalants & 0.02 \\
\hline
\end{tabular}

Crack-cocaine use in combination with amphetamines was significantly correlated with neurotic disorders $(p=$ $0.007)$ and with personality disorders $(p=0.005)$.

\section{Discussion}

The socioeconomic data on crack-cocaine users seen at the CAPSad in the city of Recife are similar to data found in national surveys. ${ }^{2,3}$ However, the average age of 29.8 (9.4) is slightly higher than the national average, which is between 18 and 24 years in state capitals. ${ }^{3}$

Studies typically show drug use in early adolescence. ${ }^{18,19}$ Early use is associated with several factors, such as, for example, as a way to enter a group, ${ }^{20}$ curiosity, ${ }^{21}$ and problems like lack of prospects ${ }^{22}$ and family breakdown. ${ }^{23}$ Continued use may trigger chemical dependency and make the user susceptible to violence by dealers because of compulsive use..$^{24,25}$ However, the average duration of drug use observed was $6.1 \pm 4.6$ years, which indicates relatively long survival when compared with studies reporting the average lifespans of people associated with crime ${ }^{26}$ or victims of trafficking. ${ }^{25}$ The maximum duration of usage of 32 years and the approximately $30 \%$ of patients who have some fixed income may indicate a usage pattern that does not directly interfere with their personal and work relationships.

Theoretically, as the cohort was selected from crackcocaine users seen at CAPSad, the patients would be expected to exhibit chemical dependence to cocaine or other drugs. That did not occur because of failures filling out records, which prevented better data analysis. It was not possible to determine whether mental disorders were caused by crack-cocaine use or were incidental comorbidities.

All mental disorders were significant correlated to each other $(p<0.04)$, except for neurotic disorders with mood disorders $(p=0.1)$. The pressures of society on people make them seek forms of relaxation and possibly seek drugs as a source of pleasure and end up becoming dependent. ${ }^{27}$ Anxiety, depression or dissociation caused by the way of life associated with drug use can lead to formation of multiple mental disorders, further hindering treatment. ${ }^{28}$ Most personality disorders were diagnosed in women $(66.7 \%)$. Although men are more impulsive in relation to women, ${ }^{29}$ there was a higher proportion of women than men suffering from personality disorders. ${ }^{30}$ The excitatory effects of crack-cocaine can cause borderline or antisocial conduct in women. ${ }^{31,32}$ These situations are normally accompanied by aggression that can cause problems of violence among users.

Multiuse was more common than isolated crackcocaine use. Although the literature reports tobacco as the main co-use $(92 \%),{ }^{3}$ in this study the main multiuse 
was a combination of alcohol, tobacco, marijuana, and crack-cocaine. It has been reported that use of marijuana and tobacco together with crack-cocaine is a way to reduce the effects of crack-cocaine craving. ${ }^{33}$ Use of alcohol in conjunction with crack-cocaine has been reported as a way to prolong the drug's effects. ${ }^{34}$ This pattern of use can be related to a form of prolonging the effects of crack-cocaine while the effects of craving are reduced, which may explain the average time of use. Although it use in conjunction of crack-cocaine and cocaine was reported, use of crack-cocaine, cocaine, and alcohol in conjunction it was not reported. Possibly because this pattern of use is related to craving. ${ }^{35}$

Other drugs used in conjunction with the crackcocaine showed a strong association with chemical dependence $(p=0.01)$. Possibly due to other drugs increasing the effects of cocaine and facilitating dependence. ${ }^{36}$ Use of alcohol and crack-cocaine together also exhibited a strong association with mood disorders $(p=0.01)$. It is probable that their use together leads to formation of cocaethylene, which has a longer halflife than cocaine ${ }^{34}$ and, due to its excitatory effects, can cause manic episodes. ${ }^{37}$ Alternatively, after use the number of excitatory neurotransmitters, particularly dopamine and noradrenalin, is reduced and so it can also cause episodes of depression. ${ }^{38}$ Use of tobacco and crack-cocaine has a strong association with schizophrenia. This is probably because they are both excitatory drugs and trigger schizotypal or paranoid states. ${ }^{39}$

The data from this study reveal strong associations between crack-cocaine use and development of mental disorders, particularly when multiuse occurs. Although cocaine dependence is the primary disorder to be treated, if associated disorders are not properly treated in patients who develop them, they can lead to recurrence. Social aspects should also be taken into account because they are often the triggers of drug use and also the reason people keep using drugs. Public services such as CAPSad should be easily accessible to the population and a government priority, to ensure better treatment for those who need support and wish to stop using crack-cocaine. These data demonstrate a need for coordination with other public policies for support and social reintegration, to provide these people with comprehensive care.

\section{Acknowledgements}

This study received financial support from Conselho Nacional de Desenvolvimento Científico e Tecnológico (CNPq). The authors are grateful to the Study Group on Alcohol and other Drugs (Grupo de Estudos sobre Álcool e outras Drogas, GEAD) for granting access to their database.

\section{References}

1. Louzã MRN, Hélio E. Psiquiatria básica. $2^{a}$ ed. Porto Alegre: Artmed; 2007.

2. Instituto Nacional de Ciência e Tecnologia para Políticas Públicas do Álcool e Outras Drogas (INPAD), II Levantamento Nacional de Álcool e Drogas (LENAD). O uso de cocaína e crack no Brasil [Internet]. 2013 [cited 2014 June 20]. inpad.org.br/lenad/ resultados/cocaina-e-crack/press-release/

3. Brasil, Ministério da Saúde, Fundação Oswaldo Cruz (FIOCRUZ), Insetituto de Comunicação e Informação Científica e Tecnológica em Saúde (ICICT). Pesquina Nacional sobre o uso de Crack [Internet]. 2014 [cited 2015 Jun 20]. icict.fiocruz.br/sites/www. icict.fiocruz.br/files/Pesquisa $\% 20$ Nacional\%20sobre $\% 200 \% 20$ Uso $\% 20$ de\%20Crack.pdf

4. United Nations Office on Drugs and Crime (UNODC). World Drug Report [Internet]. 2014 [cited 2015 Jun 20]. unodc.org/ documents/wdr2014/World_Drug_Report_2014_web.pdf

5. Edwards G, Marshall J, Cook C. O tratamento do alcoolismo. Porto Alegre: Artmed; 1999.

6. Cunha PJ, Novaes MA. Avaliação neurocognitiva no abuso e dependência do álcool: implicações para o tratamento. Rev Bras Psiquiatr. 2004;26:23-7.

7. Silveira DX, Jorge MR. Co-morbidade psiquiátrica em dependentes de substâncias psicoativas: resultados preliminares. Rev Bras Psiquiatr. 1999;21:145-51.

8. Alves H, Kessler F, Ratto LRC. Comorbidade: usos de álcool e outros transtornos psiquiátricos. Rev Bras Psiquiatr. 2004;26:513.

9. Ratto $L$, Cordeiro, DC. Principais comorbidades psiquiátricas na dependência química. In: Figlie NB, Laranjeira R, Bordin S, editores. Aconselhamento em dependência química. São Paulo: Roca; 2004. p. 167-86.

10. Zaleski M, Laranjeira RR, Marques ACPR, Ratto L, Romano M, Alves HNP, et al. Diretrizes da associação brasileira de estudos do álcool e outras drogas (ABEAD) para o diagnóstico e tratamento de comorbidades psiquiátricas dependência de álcool e outras substâncias. Rev Bras Psiquiatr. 2006;28:142-8.

11. Brasil, Ministério da Saúde. A política do Ministério da Saúde para a atenção integral a usuários de álcool e outras drogas [Internet]. 2003 [cited 2015 Jun 20]. bvsms.saude.gov.br/bvs/ publicacoes/pns_alcool_drogas.pdf

12. Parry CD, Plüddemann A, Myers BJ. Cocaine treatment admissions at three sentinel sites in South Africa (1997-2006): findings and implications for policy, practice and research. Subst Abuse Treat Prev Policy. 2007;2:37.

13. Schifano F, Corkery J. Cocaine/crack cocaine consumption, treatment demand, seizures, related offences, prices, average purity levels and deaths in the UK (1990 - 2004). J Psychopharmacol. 2008;22:71-9.

14. Borini P, Guimarães RC, Borini SB. Usuários de drogas ilícitas internados em hospital psiquiátrico: padrões de uso e aspectos demográficos e epidemiológicos. J Bras Psiquiatr. 2003;52:17197.

15. Duailibi LB, Ribeiro M, Laranjeira R. Profile of cocaine and crack users in Brazil. Cad Saude Publica. 2008;24:s545-57.

16. Horta RL, Horta BL, Rosset AP, Horta CL. [Crack cocaine users who attend outpatient services]. Cad Saude Publica. 2011;27:2263-70.

17. Uchôa RS. Entre pedras e tiros: perfil dos usuários, estratégias de consumo e impacto social do crack [database]. Process no. APQ-0957-4.06/10; CEP/CCS/UFPE no. 206/11. Recife: FACEPE/UFPE; 2012 [cited 2015 Jun 20]. http://pt.slideshare. net/JCOnLine/facepe-gead-entre-pedras-e-tiros-apresentacaoresultados-da-pesquisa-coletiva

18. Chaney RA, Rojas-Guyler L. Spatial patterns of adolescent drug use. Appl Geogr. 2015;56:71-82.

19. Brière FN, Fallu JS, Morizot J, Janosz M. Adolescent illicit drug use and subsequent academic and psychosocial adjustment: an examination of socially-mediated pathways. Drug Alcohol Depend. 2014;13545-51. 
20. Barber JG, Bolitho F, Bertrand L. Intrapersonal versus peer group predictors of adolescent drug use. Child Youth Serv Rev. 1999;21:565-79.

21. Nodora J, Hartman SJ, Strong DR, Messer K, Vera LE, White $M M$,et al. Curiosity predicts smoking experimentation independent of susceptibility in a US national sample. Addict Behav. 2014;39:1695-700.

22. Arria AM, Garnier-Dykstra LM, Cook ET, Caldeira KM, Vincent KB, Baron RA, et al. Drug use patterns in young adulthood and postcollege employment. Drug Alcohol Depend. 2013;127:23-30.

23. Salas-Wright CP, Vaughn MG, Hodge DR, Perron BE. Religiosity profiles of American youth in relation to substance use, violence, and delinquency. J Youth Adolesc. 2012;41:1560-75.

24. Kuhns JB, ClodfelterTA. Illicit drug-related psychopharmacological violence: the current understanding within a causal context. Aggress Violent Behav. 2009;14:69-78.

25. Reed E, Raj A, Falbo G, Caminha F, Decker MR, Kaliel DC, et al. The prevalence of violence and relation to depression and illicit drug use among incarcerated women in Recife, Brazil. Int J Law Psychiatry. 2009;32:323-8.

26. Aston EV. Are risk factors for drug use and offending similar during the teenage years? Int J Drug Policy. 2015;26:396-403.

27. Palmer $\mathrm{RH}$, Knopik VS, Rhee $\mathrm{SH}$, Hopfer Cl, Corley RC, Young SE, et al. Prospective effects of adolescent indicators of behavioral disinhibition on DSM-IV alcohol, tobacco, and illicit drug dependence in young adulthood. Addict Behav. 2013;38:241521.

28. Gilchrist G, Gruer L, Atkinson J. Predictors of neurotic symptom severity among female drug users in Glasgow, Scotland. Drugs (Abingdon Engl). 2007;14(4):347-65.

29. Weafer J, de Wit H. Sex differences in impulsive action and impulsive choice. Addict Behav. 2014;39:1573-9.

30. Sansone RA, Sansone LA. Gender patterns in borderline personality disorder. Innov Clin Neurosci. 2011;8:16-20.

31. Grella CE, Joshi V, Hser YI. Followup of cocaine-dependent men and women with antisocial personality disorder. J Subst Abuse Treat. 2003;25:155-64.

32. Bardeen JR, Dixon-Gordon KL, Tullb MT, Lyonsc JA, Gratz KL. An investigation of the relationship between borderline personality disorder and cocaine-related attentional bias following trauma cue exposure: the moderating role of gender. Compr Psychiatry. 2014; 55:113-22.

33. Chaves TV, Sanchez ZM, Ribeiro LA, Nappo SA. Crack cocaine craving: behaviors and coping strategies among current and former users. Rev Saude Publica. 2011;45:1168-75.

34. Harris DS, Everhart ET, Mendelson J, Jones RT. The pharmacology of cocaethylene in humans following cocaine and ethanol administration. Drug Alcohol Depend. 2003;72:169-82.

35. Fox HC, Talih M, Malison R, Andersom GM, Kreek MJ, Sinha R. Frequency of recent cocaine and alcohol use affects drug craving and associated responses to stress and drug-related cues. Psychoneuroendocrinology. 2005;30:880-91.

36. McCance-Katz EF. Drug interactions associated with methadone, buprenorphine, cocaine, and HIV medications: implications for pregnant women. Life Sci. 2011;88:953-8.

37. Moreno RA, Moreno $\mathrm{DH}$, Ratzke R. Diagnóstico, tratamento e prevenção da mania e da hipomania no transtorno bipolar. Rev Psiquiatr Clin. 2005;32:39-48.

38. El Mansari M, Guiard BP, Chernoloz O, Ghanbari R, Katz N, Blier P. Relevance of norepinephrine-dopamine interactions in the treatment of major depressive disorder. CNS Neurosci Ther. 2010;16:e1-17.

39. Ferchiou A, Szöke A, Laguerre A, Méary A, Leboyer M, Schürhoff F. Exploring the relationships between tobacco smoking and schizophrenia in first-degree relatives. Psychiatry Res. 2012;200:674-8

\section{Correspondence:}

Antonio Gomes de Castro Neto

Av. dos Engenheiros, s/no, 2nd floor, Cidade Universitária

50740-600 - Recife, PE - Brazil

Tel. : +55 (81) 99145.7531

E-mail: litaree@yahoo.com 